\title{
Developing a Measurement Model for Undergraduate Program in Logistics
}

\author{
Dazmin Daud ${ }^{1, *} \&$ Mohamed Syazwan Ab Talib ${ }^{2}$ \\ ${ }^{1}$ Chartered Institute of Logistics and Transport Malaysia, Malaysia \\ ${ }^{2}$ Faculty of Business \& Information Science, UCSI University, Malaysia \\ *Corresponding author: Chartered Institute of Logistics and Transport Malaysia, Malaysia \\ E-mail: daazmin@yahoo.com
}

Received: March 19, 2013 Accepted: April 25, $2013 \quad$ Published: May 22, 2013

doi:10.5296/ije.v5i2.3400 URL: http://dx.doi.org/10.5296/ije.v5i2.3400

\begin{abstract}
Dimensions for undergraduate degree program in logistics are very limited in literature, especially in the Malaysian scenario. This research explores the construction of measurement model on undergraduate degree program in logistics. Data on undergraduate program in logistics were gathered from 244 logistics managers using a self-administered questionnaire. Exploratory and Confirmatory Factor Analyses were used to analyze and set the dimensions. The findings show that there were three factors developed from the above analyses, namely logistics exposure, logistics curriculum, and logistician competency. Index values of $\chi^{2} / \mathrm{df}=$ 2.203; GFI $=.954$; CFI $=.938$; and $\mathrm{RMSEA}=.070$ confirm that the data fit the measurement model. The results suggest that the dimensions for the Malaysian undergraduate program may be developed from working experience, logistics courses, and management skills. These findings should be considered as a starting point for those conducting research onto Malaysian logistics educational needs.
\end{abstract}

Keywords: logistics education; logistics exposure; logistics curriculum; logistician competency 


\section{Introduction}

The era of globalization has seen the rapid advancement of the logistics industry. Malaysia, like other countries, has decided to focus on the logistics sector as part of its policies to meet global challenges (Tenth Malaysia Plan 2011-2015, 2010). This is because one of the challenges faced by Malaysia is to develop competent human resource, equipped with the right knowledge and right skills in logistics. A substantial amount of study has examined the importance of having validated dimensions of logistics program offered by higher education institutions (HEIs). Myers, Griffith, Daugherty and Lusch (2004) study has indicated a useful construct for studying dimensions of logistics program in Malaysia. Findings from Myers et al. study has demonstrated that jobs skills were found to be good predictors of logisticians' performance but not working experience and education. In a Malaysian context, studies have been done in the context of competency and talent required by logistics graduates (Lim, Dazmin \& Jonathan, 2012; Dazmin, 2011).

In the context of Malaysian economy, the growth of Malaysian business activities locally and globally requires competent logistician workforce to manage logistics activities. There is a need to prepare local logisticians to pace with the development of business globalization in the $21^{\text {st }}$ century (Department of Economic and Social Affairs of the United Nations Secretariat, 2007). A study from Wu (2007) indicated that HEIs need to provide competence and marketable logistics programs. In Malaysia, with the development of higher educational sector, more competent and marketable logistics programs need to be offered in order to meet this demand. A study from Mohamad Hanapi, Zahiruddin and Mohd Shah (2003) emphasized that it is importance for HEIs in Malaysia to cope with globalization so that the programs offered are marketable all over the world. The implementation of the Cabinet's Report in 1979, the new Private Higher Educational Act in 1996, the new Education Act 1996, and the upgrading of the National Accreditation Board to the Malaysian Qualifications Agency (MQA) in 2008, will lead to a high standard of logistics program.

While informative and intriguing, the literature still has shortcomings. Previous studies from Lim et al. (2012) and Dazmin (2011) were only focused on competency and talent needed by Malaysian logistics graduates. Studies closer to the problem were done by Wu (2007) and Myers et al. (2004) where they provide insights for developing dimensions for logistics program. However, their studies were based on the international perspectives for general logistics education.

In view of the research gap and the lack of information concerning undergraduate logistics program in Malaysia, more focus research attempts need to be carried out. One particularly interesting area would be to develop dimensions for the undergraduate logistics program offered by the Malaysian HEIs. In that, it seeks to make a first attempt in developing a measurement model indicating the dimensions that represent Malaysian undergraduate program as seen from the Malaysian logistician's perspective.

In an attempt to meet the objective of the study, specific research question that need to be addressed is identified as: what are the dimensions of Malaysian undergraduate program? For this purpose, the paper is structured as follows: a review of the literature related to 
logistics program. Following that, the next section describes the research method adopted. Next, the paper provides the results of the empirical study. Finally, brief discussions, limitations and conclusion of the paper are presented.

\section{Literature Review}

\subsection{Logistics Education Background in Malaysia}

The Malaysian government has made countless efforts to increase, improve and promote Malaysia Higher Education system both locally and internationally. Efforts such as Malaysia's National Higher Education Action Plan (2007-2010) and National Higher Education Strategic Plan (NHESP) are some of the efforts to establish Malaysia as an international hub of excellence for higher education, thus in line with the nation's drive towards Vision 2020.

Among the various programs and courses offered in various public or private HEI in Malaysia, the field of logistics and supply chain is also a popular program and course, both in undergraduate and postgraduate level. According to Lancioni, Forman and Smith (2000), logistics programs in colleges and universities around the world are upward trends and increasing in demand. Logistics and transportation higher education program in Malaysia was establish more than 40 years ago, when the Institut Teknologi MARA (now known as Universiti Teknologi MARA, UiTM) introduced Advance Diploma in Business Administration (Transport) under the Faculty of Business Management and collaboration with the Chartered Institute of Logistics and Transport (CILT).

Logistics program offered by the Malaysian HEIs is driven by demand and supply of graduates in logistics industry. Gravier and Farris (2008) defined that logistics programs are based on defining curriculum, developing content and skills, and refining teaching methods in logistics education. The purpose of the logistics program designed by the Malaysian higher education institutions is to produce competent logisticians who are equipped with accurate knowledge and skills to help logistics industry be successful over the long term. The program consists of courses for undergraduates to select and learn, and it may take several years to complete before these undergraduates are entitled to obtain their diplomas or degrees in logistics. There are two types of courses related to logistics undergraduate programs: logistics courses and non logistics courses (Dazmin, 2009). Logistics courses are courses that provide contents directly to logistics activities. On the other hand, the non logistics courses are courses that provide contents related to non logistics functional issues such as marketing, accounting, quantitative analysis, human resource management, international business, business law, management, communication, marketing, economics, etc.

Higher education institutions should ensure that all logistics programs must be able to produce competent graduates in logistics, (Fawcett, Vellenga \& Truitt, 1995) particularly when these logistics programs are related to the Supply Chain Management (SCM) (Aquino $\&$ Draper, 2008). In the beginning of the year 2000, logistics became a formal area of study in higher education institutions (Lancioni, Forman \& Smith, 2001). In that, Lancioni, Forman 
and Smith explored the challenges in logistics programs. These included the existence, levels, duration of the programs, types of higher education institutions offering the programs, and types of undergraduate logistics programs.

\subsection{Logistics Exposure}

As mentioned in the Introduction section, the study from Myers et al. (2004) has provided salient insights for the current study. In the study, when a logistician is having a situation called "educational gap" when a logistics graduate fail to apply what he has learnt from his university into working environment. The above view is supported by a study from Stevens, Gerber and Hendra (2010). Through survey, they had determined the degree to which a university approach to prior learning assessment (PLA) contributed to transformative learning. The outcomes of the study showed that respondents had developed a new sense of confidence and ability to make new meanings of experience.

Clinebell and Clinebell (2008) emphasized the need for critical courses offered to be thought by actual and experienced practitioners. They called these practitioners "executive professors" who can deliver knowledge in the course contents to match with the current educational needs of the industry. Meanwhile, Golicic, Bobbitt, Frankel and Clinton (2004) studied the gap between supply and demand of experienced logistics scholars teaching logistics courses. They concluded that there is a shortage of logistics Ph.D.s as academicians for logistics courses.

A study has been done to investigate the effects of knowledge, skills, and talent on logistics internship program within the context of Malaysian private HEIs (Lim et al., 2012). The proposed research framework and hypotheses were developed with the intention of examining the above relationship. Hierarchical regression analysis was employed to explore the relationship between knowledge, skills, talent and logistics internship program. The results revealed that talent was positively and significantly associated with logistics internship program. The study, however, has its limitation because the survey was conducted using convenience sampling and therefore, it did not represent the whole population of Malaysian undergraduate students.

\subsection{Logistics Curriculum}

A study regarding the development of logistics education can be traced back to the 1967 where there was a need to evaluate transport and logistics curricula (Cherington \& Schneider, 1967). They identified that the undergraduate education in transportation was in a state of decline while the logistics and physical distribution management had become demanding. Furthermore, their findings were supported by studies from Ballou and Piercy (1974); and Collison and Bess (1987) where HEIs were offering more transportation and logistics courses for undergraduates.

The development and influence of SCM in logistics (Fawcett, Mangan \& McCarter, 2008) show SCM programs and its courses are offered at higher education institutions. As argued by other researchers, a curriculum in logistics courses needs to be adjusted with the development of SCM (Sauber, McSurely \& Tummala, 2008; Closs \& Stank, 1999). 
Courses in logistics programs must be adapted in accordance with the development of logistics globally. This can be examined through the perspectives from prominent logistics scholars regarding the conceptual evolution in logistics (Kent \& Flint, 1997).

van Hoek (2000) argued that logistics practitioners prefer applied logistics courses at higher education institutions in their logistics programs. He emphasized that rapid changes in practice and developments of research in logistics force higher education institutions to upgrade courses in their logistics programs. van Hoek's argument was further supported by Gravier and Farris (2008). They discovered that close relationship between educators and logistics practitioners, changes of course requirements, and changes in teaching environment influence logistics educational programs in higher education institutions. In a related literature, Pteffer and Fong (2002) discussed the needs for business education to focus more on competitive programs. These programs must be able to convey knowledge that students could apply throughout their working lives.

\subsection{Logistician Competency}

There are longitudinal studies pertaining to the needs for management skills using the Business-Logistics-Management (BLM) Model (Thai, Cahoon \& Tran, 2011; Murphy \& Poist, 2007; 2006; 1998; 1994; 1991; Razzaque \& Sirat, 2001). The model was limited to the skills required by logistics managers within the scopes of business, logistics and management functions. The BLM Model has limitations. First, the target population in the longitudinal studies from 1991 to 2007 was mainly focused on the top management in logistics firms (see Thai et al., 2011; Murphy \& Poist, 2007; 1998; 1994; 1991).

Majority of items in the Business, Logistics and Management components are perceptions from the top logistics management samples except in the 2006 study. In the 2006 study, the target populations derived from senior and junior logistics managers (Murphy \& Poist, 2006). Therefore, there is still lacking in terms of studies to capture perception from other managerial levels such as middle and low.

Meanwhile, studies from Esper, Defee and Mentzer (2010) and Mangan and Christopher (2005) have indicated these points. First, in order for supply chain and logistics organizations to have a competitive advantage, they need to hire employees with key SCM skills, implement leadership styles and create learning working environment. Second, there is a challenge for logistics firms to bridge the gap on the issues of managerial skills for logistics and SCM managers.

\section{Methodology}

The objective of this study is to develop dimensions for an undergraduate logistics degree program in Malaysia. The research method was to survey Malaysian logisticians to obtain perception of the importance of undergraduate logistics program in their current positions. A total of 244 Malaysian logisticians participated in the study. A questionnaire was developed based on several literature reviews (see Table 1). Respondents were requested to 
rate the modified 12 items terms of their importance pertaining to undergraduate logistics program using a five-point Likert scale ( $1=$ extremely unimportant; $5=$ extremely important). An independent random sample of 900 Malaysian logistics firms were selected from the 2010 Malaysia Logistics Directory (www.msialogistics.com). Each respondent was sent a copy of the two-page questionnaire along with a cover letter. Two weeks later, a follow-up letter together with the same questionnaire was sent. Of these, 244 questionnaires were returned, representing 27.1 percent of the initial sample.

Table 1: Questionnaire items and their sources

\begin{tabular}{ll}
\hline \multicolumn{1}{c}{ Research focus } & \multicolumn{1}{c}{ Author(s) } \\
\hline $\begin{array}{l}\text { Actual work practice } \\
\text { Ph.D. holder }\end{array}$ & Wu (2007) \\
Delivery of knowledge and skills & Golicic et al. (2004) \\
Multi discipline syllabus & Wu (2007); Cherington and Schneider (1967) \\
Internship program & Knemeyer and Murphy (2001; 2004) \\
Knowledge, skills and competency & Gravier and Farris (2008); Knemeyer and \\
& Murphy (2001; 2004) \\
Effectiveness & Knemeyer and Murphy (2001; 2004) \\
Efficiency & Knemeyer and Murphy (2001; 2004) \\
Skill requirements & Gravier and Farris (2008); Myers et al. (2004) \\
Change course & van Hoek (2000) \\
Efficiency orientation & Wu (2007); Knemeyer and Murphy (2001; \\
& 2004) \\
Customer relationship course & Christopher, Magrill and Wills (1998) \\
& \\
\hline
\end{tabular}

An exploratory factor analysis (EFA) was conducted in order to group all the 12 items of logistician competency into common underlying factors. Principal component analysis, varimax rotation, the latent root criterion of 1.0 for factor inclusion, communalities of .5 and a factor loading of .5 was used to include items in a factor (Hair, Black, Babin \& Anderson, 2010).

A confirmatory measurement model was conducted in order to verify the posited relationships of the factors formed from the EFA. Based on Hair et al. (2010) recommendations, a maximum likelihood method was applied in order to measure the fit values for the measurement model. Indexes such as comparative fit index (CFI), root mean square error of approximation (RMSEA), and the adjusted chi-square test ( $\mathrm{X}^{2} /$ degrees of freedom) were applied to evaluate the goodness of fit for a measurement model (Anderson \& Gerbing, 1998). 


\section{1) Macrothink}

\section{Analysis and Results}

\subsection{Respondent Profile}

The results in Table 2 shows that all respondent have an average 11.4 years of working experience with large percentage are middle managers with 54.9 percent. Results also recorded that respondents come from local companies, 69.3 percent whereas 30.7 percent from multinational companies. In terms of company size, size of 500 and above recorded the largest respondent percentage with 36.5 percent.

Table 2: Respondents profile $(n=244)$

\begin{tabular}{lcc}
\hline \multicolumn{1}{c}{ Characteristics } & Frequency & Percentage \\
\hline Position & & \\
Top Manager & 43 & 17.6 \\
Middle Manager & 134 & 54.9 \\
Low Level Manager & 67 & 27.5 \\
Company Category & & \\
Multinational & 75 & 30.7 \\
Local & 169 & 69.3 \\
Company Size & & \\
1-10 & 21 & 8.6 \\
11-50 & 32 & 13.1 \\
51-100 & 20 & 8.2 \\
101-300 & 46 & 18.9 \\
301-500 & 36 & \\
500 and above & 89 & \\
Mean of working & & 11.4 years \\
experience & & \\
\hline
\end{tabular}

\subsection{Reliability Test, Kaiser-Meyer-Olkin Measure and Bartlett’s Test}

The Cronbach's Alpha value for all the 12 items were .787 signifying the reliability of the data. The value of .787 for the Kaiser-Meyer-Olkin (KMO) measure of sampling adequacy shows that the proportion of variance in the variables is influenced by underlying factors. Therefore the KMO value permits for the application of factor analysis. The KMO value is supported by the Bartlett's test of sphericity value of .00 that is less than .05. It is therefore shows that the analysis in this study is significant (Table 3).

Table 3: KMO and Bartlett's test

\begin{tabular}{llr}
\hline Kaiser-Meyer-Olkin Measure of Sampling Adequacy. & .787 \\
\hline Bartlett's Test of Sphericity & Approx. Chi-Square & 716.697 \\
& df & 66 \\
& Sig. & .000 \\
\hline
\end{tabular}




\subsection{Communalities}

Table 4 shows the proportion of variance accounted for in each item by the overall total of the 12 items. All values are above .4. This indicates that the extraction of communalities using the principal component analysis in this study is valid.

Table 4: Communalities

\begin{tabular}{ccc}
\hline Item & Initial Solution & Extraction \\
\hline LP1 & 1.000 & .532 \\
LP2 & 1.000 & .416 \\
LP3 & 1.000 & .499 \\
LP4 & 1.000 & .608 \\
LP5 & 1.000 & .652 \\
LP6 & 1.000 & .524 \\
LP7 & 1.000 & .613 \\
LP8 & 1.000 & .495 \\
LP9 & 1.000 & .634 \\
LP10 & 1.000 & .592 \\
LP11 & 1.000 & .432 \\
LP12 & 1.000 & .608 \\
Extraction Method: Principal Component Analysis.
\end{tabular}

\subsection{Total Variance Explained}

Table 5 shows the variance explained by the initial solution. Out of 12 items, only three factors demonstrated eigenvalues more than unity. In addition to that, they attributed for 55 percent for the cumulative variance. The cumulative percentage in the rotation sums of squared loadings also showed 55 percent. This shows that none of the variation explained by the initial solution is lost due to latent factors. 
Table 5: Total variance explained

\begin{tabular}{|c|c|c|c|c|c|c|c|c|c|}
\hline \multirow[b]{2}{*}{ Item } & \multicolumn{3}{|c|}{ Initial Eigenvalues } & \multicolumn{3}{|c|}{$\begin{array}{l}\text { Extraction Sums of Squared } \\
\text { Loadings }\end{array}$} & \multicolumn{3}{|c|}{$\begin{array}{l}\text { Rotation Sums of Squared } \\
\text { Loadings }\end{array}$} \\
\hline & Total & $\begin{array}{c}\% \text { of } \\
\text { Variance }\end{array}$ & $\begin{array}{c}\text { Cumulative } \\
\% \\
\end{array}$ & Total & $\begin{array}{c}\% \text { of } \\
\text { Variance }\end{array}$ & $\begin{array}{c}\text { Cumulative } \\
\% \\
\end{array}$ & Total & $\begin{array}{c}\% \text { of } \\
\text { Variance }\end{array}$ & $\begin{array}{c}\text { Cumulative } \\
\% \\
\end{array}$ \\
\hline 1 & 3.682 & 30.686 & 30.686 & 3.682 & 30.686 & 30.686 & 2.446 & 20.381 & 20.381 \\
\hline 2 & 1.815 & 15.125 & 45.810 & 1.815 & 15.125 & 45.810 & 2.320 & 19.332 & 39.713 \\
\hline 3 & 1.106 & 9.220 & 55.031 & 1.106 & 9.220 & 55.031 & 1.838 & 15.318 & 55.031 \\
\hline 4 & .918 & 7.653 & 62.683 & & & & & & \\
\hline 5 & .867 & 7.223 & 69.907 & & & & & & \\
\hline 6 & .662 & 5.513 & 75.419 & & & & & & \\
\hline 7 & .623 & 5.193 & 80.613 & & & & & & \\
\hline 8 & .579 & 4.824 & 85.436 & & & & & & \\
\hline 9 & .512 & 4.266 & 89.702 & & & & & & \\
\hline 10 & .451 & 3.757 & 93.459 & & & & & & \\
\hline 11 & .435 & 3.628 & 97.087 & & & & & & \\
\hline 12 & .350 & 2.913 & 100.000 & & & & & & \\
\hline
\end{tabular}

Extraction Method: Principal Component Analysis.

\subsection{Grouping Variables from Rotated Factor Matrix}

All 12 items are loaded into 3 factors (see Table 6). The first factor is labeled as learning outcome and evolved these five items: working experience, actual work practice and application, logistics practitioners as lecturers, internship program, and marketable graduates. The second factor can be grouped as logistics educational needs and consists of the following items: logistics knowledge, non-logistics knowledge, competency, and logistics courses offered by the HEIs. The last factor consists of three components: skills development, change module, and efficiency orientation. The components can be classified as marketable logistics graduates.

Table 6: Factor loading structure matrix

\begin{tabular}{lccc}
\hline Item & \multicolumn{3}{c}{ Factor } \\
\cline { 2 - 4 } & 1 & 2 & 3 \\
\hline LP1 & .724 & & \\
LP2 & .586 & & \\
LP3 & .648 & & \\
LP4 & .756 & & .775 \\
LP5 & & & .629 \\
LP6 & & .756 \\
LP7 & & \\
\hline
\end{tabular}




$\begin{array}{ccc}\text { LP8 } & & .610 \\ \text { LP9 } & & .783 \\ \text { LP10 } & & .667 \\ \text { LP11 } & .609 & \\ \text { LP12 } & & .760\end{array}$

\subsection{Confirmatory Factor Analysis}

A confirmatory factor analysis (CFA) of the measurement model verifying the posited relationships among the 3 factors was tested in order to measure a good fit of the model. 3 items were dropped due to the low value of standardized regression weight (less than .5). The measurement model for the three factors and the 12 items yielded a good fit to the data (CFI $=.938, \mathrm{GFI}=.954, \mathrm{RMSEA}=.070, \mathrm{X}^{2} /$ degrees of freedom $=2.203, \mathrm{p}=.001$ ) (Figure 1$)$. Correlations among the three factors were moderate and positively correlated; with Factor 1 Factor 2( $\mathrm{r}=.422, \mathrm{p}<.001)$, Factor $2-$ Factor $3(\mathrm{r}=.647, \mathrm{p}<.001)$, and Factor $1-$ Factor 3(r $=.428, \mathrm{p}<.001)$. The measurement model is shown in Figure 1

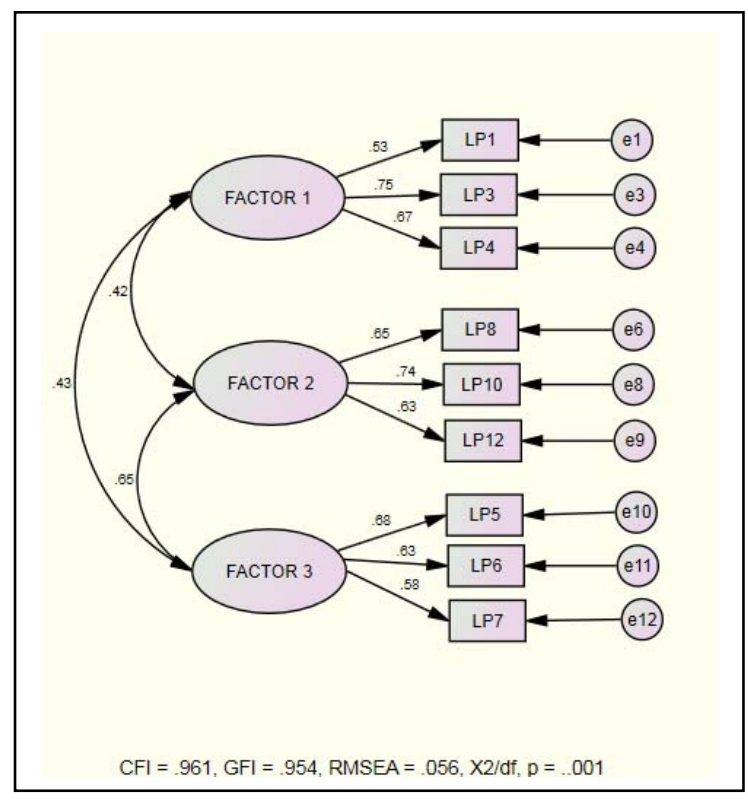

Figure 1: Measurement model for three factors of logistics program

\section{Discussion and Conclusion}

From this study, both theoretical and practical key contributions and implications can be drawn. Factor 1 labeled logistics exposure. According to Myers et al. (2004), it is crucial for logistics students to learn logistics not only in-class method but also from the actual industry. Successful learning outcome from logistics program can be achieved if major logistics subjects are thought by logistics practitioners (Golicic et al., 2004). These logistics practitioners can be hired as an adjunct lecturer or can be appointed as curriculum advisor by the Malaysian HEIs that offering logistics programs. As stated by Clinebell and Clinebell 
(2008), experienced practitioners may able to deliver relevant knowledge in academic match with the industrial current needs.

Another way to achieve a successful learning outcome from the logistics program is by emphasizing a specific duration of time for an internship program. A study from Lim et al. (2012) has demonstrated that logistics students can development their talent during internship. This study however should be development in a large scale in future in order to generalize the results. Caution should be noted in designing an effective internship program. A too short internship (such as 1 month) may not able for the students to learn and acquire proper hands on knowledge and skills. Views from logistics practitioners can provide better insight pertaining to an ideal duration for the internship. In addition to that, they may suggest what kind of logistics firms are suitable for the students.

Factor 2 reflects on logistics curriculum and consists of logistics knowledge, non-logistics knowledge, competency and courses offered. Logistics curriculum is expected to produce learning outcomes that graduates in a logistics program will able to understand business logistics (Thai et al., 2011; Wu, 2007). This is an important issue because the students must able to apply knowledge when they work in logistics industry (van Hoek, 2000). In another view, Lancioni, Forman and Smith (2001) mentioned that there are HEIs that failed to design effective curriculum for logistics programs. The perspectives of these HEIs' logistics curriculum were more on local needs but were not designed for international setting.

In addition, logistics curriculum must also be equipped with non-logistics knowledge and capabilities for example finance, sales, marketing, customer service, information system and so forth, along with in-depth understanding in logistics (Thai et al., 2011, Busse \&Wallenburrg, 2011; Wu, 2007; Razzaque \& Sirat, 2001). This is because, in order to face global challenges in a globalized market, logisticians are required to have an overall knowledge and skills.

Items forming Factor 3 view Malaysian logistician competency on skills development, change, and efficiency. Pohlen (2011) suggested that for logistics graduates to demonstrate a competent worker, they must be able to apply knowledge and skills from their HEIs in practical situation.

The importance of change management has been emphasized in the BLM studies (see Murphy \& Poist, 2007; 2006; 1998; Razzaque \& Sirat, 2001). Furthermore, findings from Heilmann (2007) indicated that changes in organizations such as new demanding duties and technological development require continuous training and updating of knowledge for workers.

This study has shown the importance of efficiency elements in logistics program. Respondents had emphasized that courses in logistics program must contribute to produce competent logistics graduates so that these graduates will perform their roles efficiently. The findings support previous studies regarding the important of efficiency in logistics education (for examples see Burcher, Lee \& Sohal, 2005; Rao, Stenger \& Wu, 1998). 
From this study it signifies the implication of higher education institutions (HEIs) and logistics education are logistics exposure, logistics curriculum, and logistician competency. In order for logistics graduates to achieve competency, the learning outcome must be able to be learnt and applied by the graduates.

Besides that, this study can be used as a general guideline for recruitment and development of logisticians among the employers. For instance, during recruitment process and to determine the level of competency, potential logistician may be tested on their exposure towards logistics industry, skills, business knowledge, and leadership skills. Plus, the findings from this study may be use as a check-list kit to conduct an audit for measuring employees' competency among the employers.

However, few limitations from this study need to be highlighted. Firstly, this study is only limited to managerial positions in logistics companies (top, middle and low managers) which limit the generalize ability of the findings. It is recommended that for future research, survey on logisticians who do not posed any managerial positions can also be included. Secondly, demographical factors such as working experience, managerial position, company category, and company size may have implication on how well the respondents may have understood and perceived the concept of "logistics education". A large sample size may improve generalize ability for future research on "logistics education". Finally, the study is a cross-sectional in nature where it limits one's ability to capture changes in perception over time. Perhaps a sugestion on longitudinal research design could provide more reliable on results for future research.

In conclusion, logistics exposure, logistics curriculum, and logistician competency are indicated by EFA and CFA results of Malaysian logistician education. These three dimensions provide salient inputs to Malaysian HEIs and also logistics managers for tapping competency in logistics programs, recruitment and development functions. Therefore the study confirms the determining factors that comtributes to undergraduate logistics program will be the major study in the Malaysian logistics industry.

\section{References}

Anderson, J. C., \& Gerbing, D. W. (1988). Structural Equation modeling in practice: A review and recommended two-step approach. Psychological Bulletin, 103(3), 411-423. http://dx.doi.org/10.1037/0033-2909.103.3.411

Aquino, D., \& Draper, L. (2008). Supply chain talent: State of discipline. AMR Research.Retrieved March 3, 2013 from http://archive.supply-chain.org/galleries/publicgallery/SupplyChainTalent_StateoftheDis cipline.pdf

Ballou, R.H., \& Piercy, J.E. (1974). A survey of current status and trends in transportation and logistics education. Transportation Journal, 14(2), 27-36. 
Burcher, P.G., Lee, G.L., \& Sohal, A.S. (2005). A cross country comparison of careers in logistics management in Australia and Britain. International Journal of Physical Distribution \& Logistics Management, 16(2), 205-217. http://dx.doi.org/10.1108/09574090510634511

Busse, C., \& Wallenburg, C.M. (2011). Innovation management of logistics service providers: Foundations, review, and research agenda. International Journal of Physical Distribution $\begin{array}{llll}\text { \& Logistics } & \text { Management, } & 41(2), & \text { 187-218. }\end{array}$ http://dx.doi.org/10.1108/09600031111118558

Cherington, P.W., \& Schneider, L.M. (1967). Transportation and logistics education in graduate schools of business administration - A summary report. Transportation Journal, 7(2), 19-26.

Christopher, M., Magrill, L., \& Wills, G. (1998). Educational development for marketing logistics. International Journal of Physical Distribution \& Logistics Management, 28(4), 234-41. http://dx.doi.org/10.1108/09600039810222684

Clinebell, S.K., \& Clinebell, J.M. (2008). The tension in business education between academic rigor and real-world relevance: The role of executive professors. Academy of $\begin{array}{llll}\text { Management Learning \& } \quad \text { Education, } & \text { 7(1), }\end{array}$ http://dx.doi.org/10.5465/AMLE.2008.31413867

Closs, D. J., \& Stank, T. P. (1999). A cross-functional curriculum for supply chain education at Michigan State University. Journal of Business Logistics, 20(1), 59-72.

Collison, F.M., \& Bess, H.D. (1987). Transportation and logistics curricula: A new look. Journal of Business Logistics, 8(1), 79-95.

Dazmin, D. (2009). Collaboration for logistics education in Malaysia. Bulletin of Higher Education Research, 13(June), 19-21.

Dazmin, D. (2011). Knowledge as a Mediating Factor towards Competency and Logistics Programme Relationship: Perspective from Logistics Practitioners. Anvesha, 4(1), 1-11.

Department of Economic and Social Affairs of the United Nations Secretariat (2007). Industrial Development for the $21^{\text {st }}$ Century: Sustainable Development Perspectives. United Nations: New York.

Esper, T.L., Defee, C.C., \& Mentzer, J.T. (2010). A framework of supply chain orientation. International Journal of Logistics Management, 21(2), 161-179. http://dx.doi.org/10.1108/09574091011071906

Fawcett, S. E., Vellenga, D. B., \& Truitt, L.J. (1995). An evaluation of logistics and transportation professional organizations, programs, and publications. Journal of Business Logistics, 16(1), 299-314. 
Fawcett, S.E., Mangan, G.M., \& McCarter, M.W. (2008). Benefits, barriers, and bridges to effective supply chain management. Supply Chain Management: An International Journal, 13(1), 35-48. http://dx.doi.org/10.1108/13598540810850300

Golicic, S.L., Bobbitt, L.M., Frankel, R., \& Clinton, S.R. (2004). And who will teach them? An investigation of the logistics Phd market. Journal of Education for Business, 80(1), 47-51. http://dx.doi.org/10.3200/JOEB.80.1.47-51

Gravier, M.J., \& Farris, M.T. (2008). An analysis of logistics pedagogical literature. The International Journal of Logistics Management, 19(2), 233-253. http://dx.doi.org/10.1108/09574090810895979

Hair, J.F., Black, W.C., Babin, B.J., \& Anderson, R.E. (2010). Multivariate Data Analysis: A Global Perspective ( $7^{\text {th }}$ ed.). Pearson: Boston, MA.

Heilmann, P. (2007). High level competence: A tool for coping with organizational change. Journal of European Industrial Training, 31(9), 727-741. http://dx.doi.org/10.1108/03090590710846684

Kent, J.L. Jr., \& Flint, D.J. (1997). Perspective on the evolution of logistics thought. Journal of Business Logistics, 18(2), 15-29.

Knemeyer, A.M., \& Murphy, P.R. (2001). Logistics internships: Employer perspectives. Transportation Journal, 41(1), 16-26.

Knemeyer, A.M., \& Murphy, P.R. (2004). Promoting the value of logistics to future business leaders: An exploratory study using a principles of marketing experience. International Journal of Physical Distribution \& Logistics Management, 34(10), 775-792. http://dx.doi.org/10.1108/09600030410571356

Lancioni, R., Forman, H., \& Smith, M. (2000). Logistics programmes in universities: Stovepipe vs. cross disciplinary. International Journal of Physical Distribution \& Logistics Management, 31(1), 53-64. http://dx.doi.org/10.1108/09600030110366429

Lancioni, R., Forman, H., \& Smith, M.F. (2001). Logistics and supply chain education: Roadblocks and challenges. International Journal of Physical Distribution \& Logistics Management, 31(10), 733-745. http://dx.doi.org/10.1108/EUM0000000006287

Lim, Y.P., Dazmin, D., \& Jonathan, K.R. (2012). Perceptions of logistics students on internship programme: The case of private higher institution in Malaysia. Canadian Social Research, 8(4), 1-7. http://dx.doi.org/10.3968/j.css.1923669720120804.1123

Mangan, J., \& Christopher, M. (2005). Management development and the supply chain manager of the future. The International Journal of Logistics Management, 16(2), 178-191. http://dx.doi.org/10.1108/09574090510634494

Mohamad Hanapi, M., Zahiruddin, G., \& Mohd Shah, K. (2003). The development of global education in Malaysia: Strategies for internationalization. Malaysian Management Review, 38(2), 75-86. 
Murphy, P.R., \& Poist, R.F. (1991). Skill requirements of senior-level logisticians: Practitioner perspectives. International Journal of Physical Distribution \& Logistics Management, 21(3), 3-14. http://dx.doi.org/10.1108/09600039110004025

Murphy, P.R., \& Poist, R.F. (1994). Educational strategies for succeeding in logistics: A comparative analysis. Transportation Journal, 33(3), 36-48.

Murphy, P.R., \& Poist, R.F. (2006). Skill requirements of contemporary senior-and entry-level logistics managers: A comparative analysis. Transportation Journal, 45(3), 46-60.

Murphy, P.R., \& Poist, R.F. (2007). Skill requirements of senior-level logisticians: A longitudinal assessment. Supply Chain Management: An International Journal, 12(6), 423-431. http://dx.doi.org/10.1108/13598540710826353

Murphy, P.R., \& Poist, R.F. (1998). Skill requirements of senior-level logisticians. International Journal of Physical Distribution \& Logistics Management, 28(4), 284-301. http://dx.doi.org/10.1108/09600039810222747

Myers, M.B., Griffith, D.A., Daugherty, P.J., \& Lusch, R.F. (2004). Maximizing the human capital equation in logistics: Education, experience, and skills. Journal of Business Logistics, 25(1), 211-232. http://dx.doi.org/10.1002/j.2158-1592.2004.tb00175.x

Pohlen, T.L. (2011). Meeting the challenge of educating the transportation and logistics professional: The American Society of Transportation and Logistics on the 50th anniversary of Transportation Journal. Transportation Journal, 50(1), 84-90.

Pteffer, J., \& Fong, C.T. (2002). The end of business schools? Less success than meets the eye. Academy of Management Learning \& Education, 1(1).78-95.

Rao, K., Stenger, A.J., \& Wu, H. (1998). Integrating the use of computers in logistics education. International Journal of Physical Distribution \& Logistics Management, 28(4), 302-319. http://dx.doi.org/10.1108/09600039810222756

Razzaque, M.A., \& Sirat, M.S. (2001). Skill requirements: perception of the senior Asian logisticians. International Journal of Physical Distribution \& Logistics Management, 31(5), 374-395. http://dx.doi.org/10.1108/09600030110395175

Sauber, M.H., McSurely, H.B., \& Tummala, V.M.R. (2008). Developing supply chain management program: A competency model. Quality Assurance in Education, 16(4), 375-391. http://dx.doi.org/10.1108/09684880810906517

Stevens, K., Gerber, D., \& Hendra, R. (2010). Transformational learning through prior learning assessment. Adult Education Quarterly, 60(4), 377-404. http://dx.doi.org/10.1177/0741713609358451

Tenth Malaysia Plan 2011-2015. (2010). The Economic Planning Unit. Prime Minister's Department, Putrajaya, Malaysia. 
Thai, V.V., Cahoon, S., \& Tran, H.T. (2011). Skill requirements for logistics professionals: Findings and implications. Asia Pacific Journal of Marketing and Logistics, 23(4), 553-574. http://dx.doi.org/10.1108/13555851111165084

van Hoek, R.I. (2000). Logistics education: Achieving market and research driven skill development. International Journal of Physical Distribution \& Logistics Management, 31(7/8), 505-519. http://dx.doi.org/10.1108/EUM0000000005906

Wu, Y.J. (2007). Contemporary logistics education: An international perspective. International Journal of Physical Distribution \& Logistics Management, 37(7), 504-528. http://dx.doi.org/10.1108/09600030710776455

\section{Copyright Disclaimer}

Copyright reserved by the author(s).

This article is an open-access article distributed under the terms and conditions of the Creative Commons Attribution license (http://creativecommons.org/licenses/by/3.0/). 